\title{
A NEW SPECIES OF THE GENUS STIRELLUS OSBORN ET BALL, 1902 (HEMIPTERA: AUCHENORRHYNCHA: CICADELLIDAE: DELTOCEPHALINAE) FROM THE UNITED ARAB EMIRATES
}

\author{
VladimiR M. GNEZDilov \\ Zoological Institute, Russian Academy of Sciences \\ Universitetskaya Emb. 1, St. Petersburg 199034, Russia; \\ E-mail:vmgnezdilov@mail.ru,vgnezdilov@zin.ru; https://orcid.org/0000-0002-7331-8744
}

Stirellus desertus sp. n. is described after male and female specimens collected in Sharjah of the United Arab Emirates. This is the first record of the tribe Stenometopiini Baker from the country.

Key words: Arabian Peninsula, new species, Stenometopiini, Stirellus, Cicadellidae.

\section{INTRODUCTION}

The genus Stirellus Osborn et Ball, 1902 is "a large and heterogeneous assemblage of species distributed worldwide" currently includes 25 other names of generic level considered as junior synonyms with more than 90 species described (Dmitriev 2003, Duan et al. 2016, 2019). This genus belongs to the tribe Stenometopiini Baker, 1923 together with the monotypical Kinonia Ball, 1933, known from USA and Mexico, and Hodoedocus Jacobi, 1910 which comprises seven Old World species (tropical Africa, Oriental Region, and Australia), and one New World species (Guatemala) (DMitriev 2003, Duan et al. 2019).

The species of the genus Stirellus are characterized by the frons without median carina and the aedeagus with long and narrow, often s-shaped, shaft. The new species described below was collected by sweeping in Sharjah Desert National Park during my field trip to the United Arab Emirates in April 2010 in frame of the project targeting the arthropod fauna of the UAE directed by Dr. Antonios van Harten (Almada, Portugal), and represents the first record of the tribe Stenometopiini Baker from the country.

\section{MATERIAL AND METHODS}

The photographs were taken using light microscope Leica MZ9.5 and a Leica DFC 490 camera. Images were produced using Helicon Focus V. 6.7.1 and Adobe Photoshop software. The genital segments of the examined specimen were macerated in $10 \% \mathrm{KOH}$ and figured in glycerine jelly (Brunel Micro Ltd, UK) using same microscope with camera lucida.

The type series of the species described below are deposited in the Zoological Institute of the Russian Academy of Sciences, Saint Petersburg, Russia. 


\section{TAXONOMY}

Cicadellidae Latreille, 1802

Deltocephalinae Dallas, 1870

Stenometopiini Baker, 1923

Genus Stirellus Osborn et Ball, 1902: 250.

Type species: Athysanus bicolor Van Duzee, 1892.

Diagnosis (after Zahniser \& Dietrich 2013, Duan et al. 2016, 2019, modified). Vertex with anterior margin rounded or elongately produced. Frons without median carina. Forewings variably developed, usually with three anteapical cells, with inner one basally opened; membrane reduced; veins not raised. Male pygofer sloping caudoventrally, with macrosetae reduced in number or absent, often with a lateral tooth on each lobe. Male anal tube long. Genital valve large, triangular-shaped. Connective Y-shaped or H-shaped. Aedeagus with long and narrow, often S-shaped, single shaft and single gonopore. Ovipositor protruding far beyond the pygofer apex.

\section{Stirellus desertus sp. n.}

(Figs 1-16)

Type material. Holotype, male, United Arab Emirates, Sharjah Desert Park, N $25^{\circ} 16.859^{\prime}$ E 5541.422', 10.IV.2010, V.M. Gnezdilov leg. Paratype, female, United Arab Emirates, Sharjah Desert Park, N 25⒗859’ E 5541.422', 10.IV.2010, V. M. Gnezdilov leg.

Description. Structure. Vertex triangularly elongate, with tiny median groove, nearly twice as long as wide between the eyes, with rounded apex (in dorsal view) (Figs 1, 3). Frons and vertex joint at acute angle (in lateral view) (Figs 2, 4). Rostrum short, apical segment
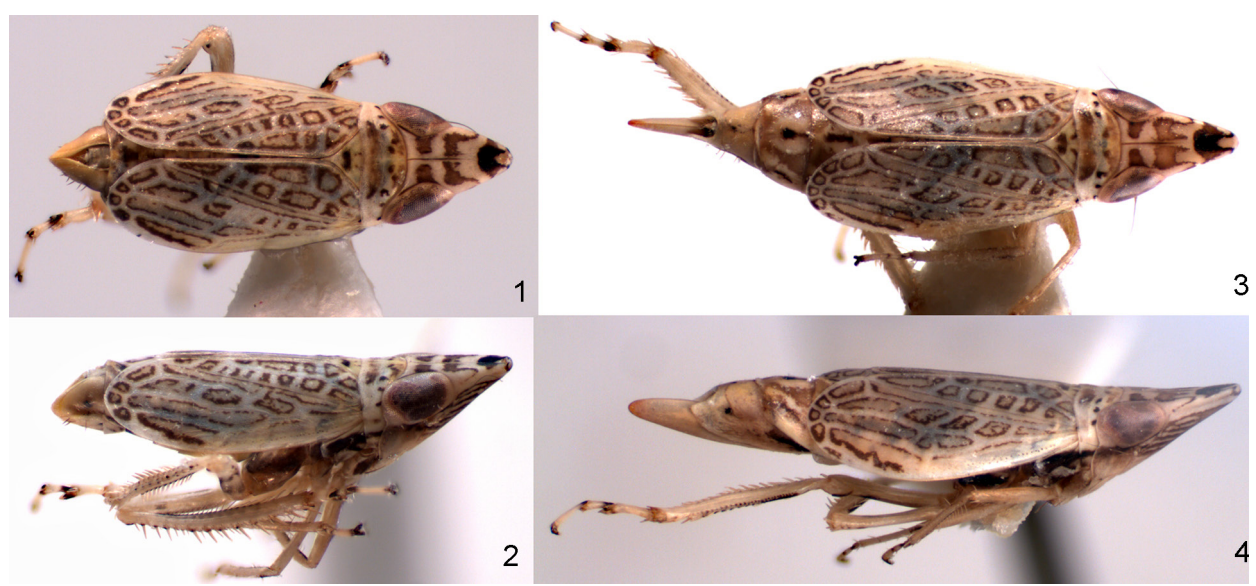

Figs 1-4. Stirellus desertus sp. n.: 1 = male, holotype, dorsal view, 2 = same, lateral view, 3 = female, paratype, dorsal view, 4 = same, lateral view. Male $3.0 \mathrm{~mm}$, female $5.0 \mathrm{~mm}$ 
cylindrical. Pronotum half as long as vertex at midline. Mesonotum slightly shorter than pronotum, with transverse groove. Forewings reaching hind margin of 7 th tergite, with clavus $3 / 4$ as long as whole wing. Forewings with reduced membrane, venation smooth. Hind wings not visible, apparently rudimentary. Hind femora with $2+1+1$ apical spines.

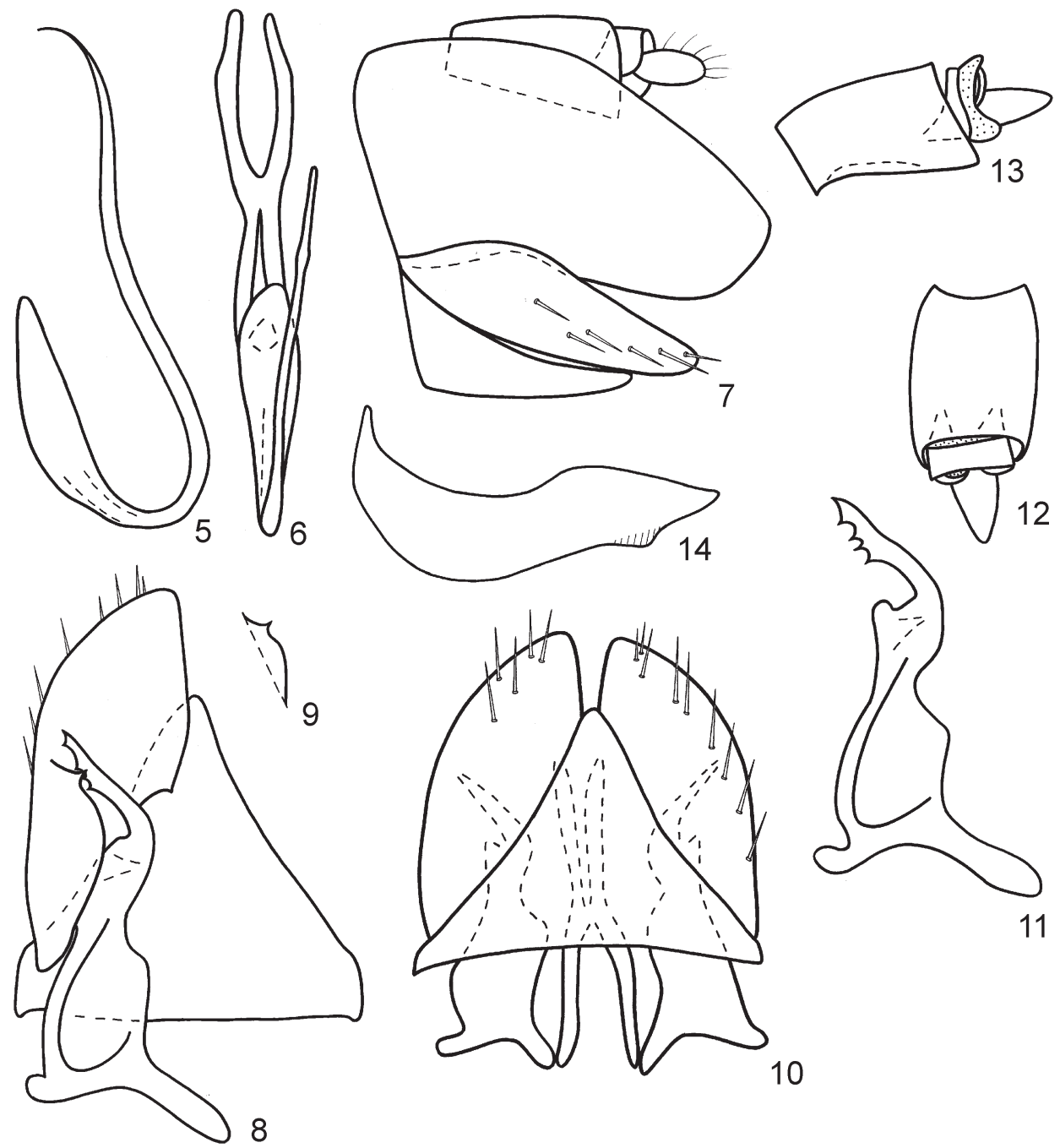

Figs 5-14. Stirellus desertus sp. n., holotype, male genitalia: $5=$ aedeagus, lateral view, $6=$ aedeagus and connective, dorsal view, 7 = genital block without aedeagus and styles, lateral view, 8 = genital valve, subgenital plate, and style, dorsal view, $9=$ tooth of the lobe covering style on subgenital plate, dorsal view, $10=$ genital valve, subgenital plates, and styles, ventral view, 11 = style, dorsal view, 12 = anal tube, dorsal view, $13=$ anal tube, lateral view, 14 = right lobe of pygofer, dorsal view 
Colouration. General colouration light yellow whitish (Figs 1-4). Frons darkened, except below its upper margin, with transverse yellow stripes besides of median line. Gena with wide brown cross band below the eye. Vertex with three pairs of large brown to dark brown comma-shaped spots-apical spots fused below apex of vertex and two pairs of spots behind are separated medially; median line dark brown between the spots (Figs 1, 3). Rostrum dark brown apically.

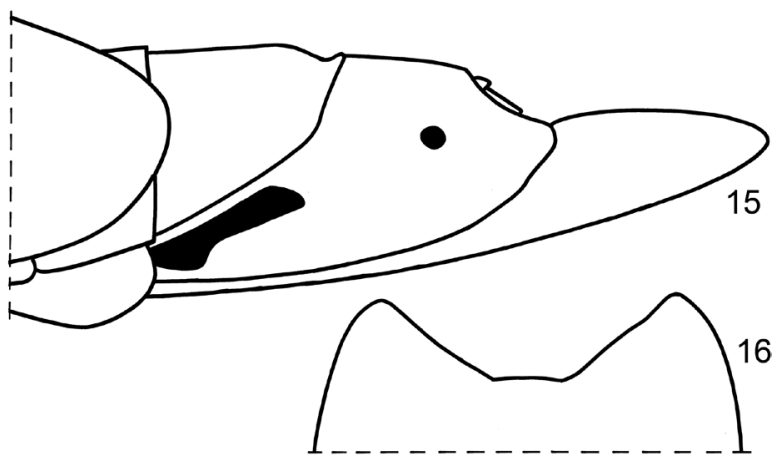

Figs 15-16. Stirellus desertus sp. n., paratype, female genitalia: 15 = ovipositor, lateral view, $16=$ sternum VII, ventral view Pronotum with light brown anterior margin, with $10(3+2+2+3)$ brown to dark brown spots along the margin, and with transverse light brown stripe along posterior margin. Mesonotum with transverse dark brown stripe below the groove separating scutellum and with two brown spots below anterior margin. Fore wings with cells margined by brown stripes inside. Thorax from below and coxae anteriorly dark brown. Tibiae with dark brown dots at the bases of macrosetae. Inner margins of hind femora dark brown in a female. Apices of tarsomeres and claws from brown to dark brown. Abdominal sternites dark brown laterally. Laterotergites III dark brown almost completely. Laterotergites IV-VII partly dark brown and yellowish. Female abdominal tergites with dark brown median stripe. Female pygofer with elongate brown stripe laterally and with dark brown spot subapically on each side (Figs 4, 15).

Male genitalia (Figs 5-14). Anal tube elongately cylindrical (Figs 12, 13). Pygofer lobe with caudal margin at obtuse angle (Fig. 7), without lateral tooth, but with a subapical swelling visible only in dorsal view (Fig. 14). Subgenital plates as long as pygofer lobes in lateral view, with macrosetae on lateral margines and with a tooth on the inner lobe covering style (Figs 8-10). Genital valve large, triangular-shaped (Figs 8, 10). Connective with a stem as long as the arms (Fig. 6). Style with four subapical teeth (Fig. 11). Aedeagus with long S-shaped shaft, twice as long as aedeagal basement (in lateral view) (Fig. 5).

Female genitalia (Figs 15, 16). Ovipositor protruding far beyond the pygofer apex (Fig. 15). Hind margin of sternum VII deeply concave medially (Fig. 16).

Total length. Male $-3.0 \mathrm{~mm}$. Female $-5.0 \mathrm{~mm}$.

Etymology. The species name refers to the type of biotope where it was collected sand desert.

\section{DISCUSSION}

According to elongate, triangular-shaped vertex the new species described above is close to Stirellus capitatus (Distant, 1918), known from the Oriental Region (Duan et al. 2016), S. mitis (Kirkaldy, 1906), distributed in Austral- 
ian Region, S. atropunctus (Gillette, 1898) and S. fasciatus (Ball et Beamer, 1940) from the Nearctics, and to S. acuticeps (Ribaut, 1948) and S. pallifrons (Horváth, 1897), both known from the Western Palaearctic Region (Gillette 1898, HoRváth 1897, Ball \& Beamer 1940, DeLong 1948, Oman 1949, Ribaut 1948, Evans 1966, Nast 1972, Emeljanov et al. 2002). However, the new species is well distinguished by the coloration of the head and forewings - brown to dark brown comma-shaped spots on the vertex (Figs 1,3) and forewings with cells margined by brown stripes inside (Figs 1-4). Other mentioned species are monotonously yellow greenish from above, except, S. mitis, S. atropunctus, and S. fasciatus having dark spots or stripes on vertex. $S$. fasciatus differs from $S$. desertus sp. n., as well as from $S$. mitis and S. atropunctus, by shorter vertex which is just "slightly longer at middle than width between eyes" (BALl \& BeAmer 1940). S. mitis is distinguished by brown apex of vertex, with two regular brown cross bands behind (Evans 1966, fig. 35, G 1), while S. atropunctus is characterized by light yellow vertex with a black spot at apex (GILleTte 1898).

The species figured by DeLong (1948) as S. atropunctus differs from original description given by GiLlette (1898), based on two females, by the presence of four dark spots on vertex widely separated in the middle (DELong 1948, fig. 210) which were not mentioned by Gillette when he wrote about S. atropunctus's vertex "...light yellow shaded with brown towards the apex, paler between the eyes, median stripe and two cross bars whitish, median dark line obsolete except at the base..." (Gillette 1898, p. 28). Apparently DeLong (1948) published the drawing of the head of another species from Illinois different from S. atropunctus Gillette described from Colorado in USA. Also Oman (1949) characterizing the genus Gillettiella Osborn, 1930 (junior synonym of Stirellus) mistakenly mentioned rounded anterior margin of vertex for all species including S. atropunctus even Gillette (1898) and BALL and BEAMER (1940) noticed vertex strongly produced and acute for this species.

The tribe Stenometopiini Baker was known from Arabian Peninsula after the record of Stirellus instabilis (Ribaut, 1948) from Saudi Arabia by Dlabola (1979), but it is first record of the tribe from the United Arab Emirates, the cicadellid fauna of which is still in its initial stage of discovering (GNEzDILOv 2019).

Acknowledgements - I am glad to thank Dr. Antonios van Harten (Almada, Portugal) for providing my field work in the UAE and Dr. Michael R. Wilson (Cardiff, UK) for his company in the field, Dr. Dmitry A. Dmitriev (Champaign, Illinois, USA) for his help with literature, Dr. Christopher H. Dietrich (Champaign, Illinois, USA) for discussion of the taxonomic position of the species described, and the anonymus reviewers for their valuable suggestions for improvement of the manuscript.

The study was performed in the framework of the Russian State Research project № AAAA-A19-119020690101-6. 


\section{REFERENCES}

Ball, E. D. \& Beamer, R. H. (1940): A revision of the genus Athysanella and some related genera (Homoptera-Cicadellidae). - The Kansas University Science Bulletin 26: 5-82.

DeLong, D. M. (1948): The leafhoppers, or Cicadellidae, of Illinois (Eurymelinae-Balcluthinae). - Bulletin of the Illinois Natural History Survey 24(2): 97-376.

Dlabola, J. (1979): Homoptera. Insects of Saudi Arabia. Fauna of Saudi Arabia 1: 115-139. https://doi.org/10.1007/978-1-349-03214-3_1

Dmitriev, D. A. (2003): online. 3i World Auchenorrhyncha Database. -http://dmitriev.speciesfile.org/ [Accessed on May 24, 2019]

Duan, Y., Webs, M. D. \& Zhang, Y. (2016): Review of the leafhopper tribe Stenometopiini (Hemiptera: Cicadellidae: Deltocephalinae) from China with description of four new species. - Zootaxa 4171(1): 101-138. https://doi.org/10.11646/zootaxa.4171.1.4

Duan, Y., Zhang, Y. \& Dietrich C. H. (2019): Six new species of Stenometopiini (Hemiptera: Cicadellidae: Deltocephalinae) with redescription of additional species and new distributional records. - Zootaxa 4603(2): 201-240. https://doi.org/10.11646/zootaxa.4603.2.1

Emeljanov, A. F., Gnezdilov, V. M. \& Gjonov I. V. (2002): Addenda to the fauna of Cicadina (Hemiptera) of Bulgaria. - Acta Entomologica Slovenica 10(1): 83-90.

Evans, J. W. (1966): The leafhoppers and froghoppers of Australia and New Zealand (Homoptera: Cicadellidae and Cercopidae). - The Australian Museum Memoir 12: 1-347. https://doi.org/10.3853/j.0067-1967.12.1966.425

Gillette, C. P. (1898): A few new species of Deltocephalus and Athysanus from Colorado. - Bulletin of the Agricultural Experiment Station of the Colorado Agricultural College 43(3): 23-29.

Gnezdilov, V. M. (2019): Leafhoppers of the subtribe Paradorydiina Evans (Hemiptera, Auchenorrhyncha: Cicadellidae) in the United Arab Emirates. - Zoosystematica Rossica 28(1): 155-162. https://doi.org/10.31610/zsr/2019.28.1.155

Horváth, G. (1897): Homoptera nova ex Hungaria. - Természetrajzi Füzetek 20: 620-643.

Nast, J. (1972): Palaearctic Auchenorrhyncha (Homoptera). An annotated check list. - Polish Scientific Publishers, Warszawa, 550 pp.

Oman, P. W. (1949): The Nearctic leafhoppers (Homoptera: Cicadellidae). A generic classification and check list. - Memoires of the Entomological Society of Washington 3: 1-253.

Osborn, H. \& Ball, E. D. (1902): A review of the North American species of Athysanus (Jassidae). - The Ohio Naturalist 2(6): 231-256.

Ribaut, H. (1948): On the insect fauna of Cyprus. Results of the expedition of 1939 by Harald, Håkan and P. H. Lindberg. III. Homoptères nouveaux de Chypre. - Commentationes Biologicae 10(8): 3-14.

Zahniser, J. N. \& Dietrich C. H. (2013): A review of the tribes of Deltocephalinae (Hemiptera: Auchenorrhyncha: Cicadellidae). - European Journal of Taxonomy 45: 1-211. https://doi.org/10.5852/ejt.2013.45

Received May 24, 2019, accepted September 12, 2019, published March 6, 2020 